\title{
Effectiveness of Hydrogel Application on Tomato (Solanum lycopersicum L.) Growth and some Sandy Soil Chemical Properties under Drip Irrigation System
}

\author{
Noha A. Mahgoub \\ Soil and Water Department, Faculty of Agriculture, Suez Canal University, 41522 Ismailia, Egypt
}

Received: $18 / 7 / 2020$

\begin{abstract}
A field experiment was conducted at the experimental site of Faculty of Agriculture of Suez Canal University, Ismailia, Egypt, to evaluate the effect of hydrogel addition on tomato (Solanum lycopersicum L.) growth and some soil chemical properties. The experiment was laid out in a randomized complete block design having six treatments with three replicates as follow: control, two hydrogel levels $\left(\mathrm{HG}_{1}, 2 \mathrm{~g}\right.$ plant ${ }^{-1}$ and $\mathrm{HG}_{2}, 4 \mathrm{~g}$ plant $\left.{ }^{-1}\right)$, recommended fertilizers for tomato (F) and combination of hydrogel and half amounts of recommended fertilizers $\left(\mathrm{HG}_{1}+0.5 \mathrm{~F}\right.$ and $\left.\mathrm{HG}_{2}+0.5 \mathrm{~F}\right)$. The obtained results showed that hydrogel application to plants with $4 \mathrm{~g}$ hydrogel + half the recommended amount of fertilizer $\left(\mathrm{HG}_{2}+0.5 \mathrm{~F}\right)$ enhanced nitrogen $(\mathrm{N})$, phosphorus $(\mathrm{P})$ and potassium $(\mathrm{K})$ content of fruits. The highest value of root dry weight was obtained with the treatment $\left(\mathrm{HG}_{1}+0.5 \mathrm{~F}\right)$. Also, the highest dry weight of the shoots was in the case of treatments $\left(\mathrm{HG}_{1}+0.5 \mathrm{~F}\right)$ and $\left(\mathrm{HG}_{2}+0.5 \mathrm{~F}\right)$. The highest weight of fruits was recorded in the treatment of $4 \mathrm{~g}$ hydrogel plant ${ }^{-1}\left(\mathrm{HG}_{2}\right)$. Also, adding $2 \mathrm{~g} \mathrm{plant}^{-1}\left(\mathrm{HG}_{1}\right)$ hydrogel and $4 \mathrm{~g} \mathrm{plant}^{-1}\left(\mathrm{HG}_{2}\right)$ reducing $\mathrm{pH}$ ranged between 0.08-0.18 units. The addition of hydrogel at the rate of $\left(4 \mathrm{~g} \mathrm{plant}^{-1}\right)$ with half of the recommended amounts of fertilizers $\left(\mathrm{HG}_{2}+0.5 \mathrm{~F}\right)$ led to an increase in the value of the soil cation exchange capacity (CEC) from $9.30 \pm 0.12$ to $11.5 \pm 0.12$ and increased available nutrients from $3.47 \pm 0.15$ to $15.8 \pm 0.9,21 \pm 1.5$ to $78 \pm 1.5$ and $283 \pm 4$ to $343 \pm 23 \mathrm{mgkg}^{-1}$, for N, P and K, respectively.
\end{abstract}

Keywords: Hydrogel, Tomato growth, nutrients uptake, Soil chemical properties, Sandy soils, Drip Irrigation

\section{INTRODUCTION}

Sandy soils have several limitations for agricultural production, including low fertility, poor water retention, and tendency to wind erosion on dunal sands (Hoang et al., 2010). Because of the high porosity of sands, excessive losses of water and leaching of fertilizers will occur, particularly if surface irrigation methods are used (El-Hady et al., 2003). Hydroabsorbents or hydrogels can play an important role in increasing water availability in sandy soils. They are known to increase water holding capacity of soil, they may be a proper technique to enhance water and fertilizers use efficiencies (Dehkordi and Seyyedboveir, 2013).

Hydrogel is a hydrophilic cross-linked biodegradable polymer that can absorb water by 100 times the original weight in a short time. When hydrogel is applied to soil, it forms an amorphous gelatinous mass upon hydration, resulting in water absorption and desorption over a long period of time. As a result, it acts as a slow-release water source in the soil. The granule size of the hydrogels, moisture of the background soil, degree of crosslinking, and solubility of the active agents are the factors that influence nutrient release from controlled released fertilizer (Yousefzadeh et al., 1994). Also, controlled released fertilizers have considered a proper way to reduce fertilizer loss through irrigation water effects, providing long-term nutrition, reducing pollution for the environment, and minimizing the use of fertilizers.

The aim of this research is to study the effect of hydrogel fertilizer which is known commercially barbary plante when it mixed with soil or conventional fertilizer, on soil chemical properties and plant growth in sandy soils under drip irrigation. Tomato plant (Solanum lycopersicum L.) was chosen because it is one of the main vegetable crops that need to be cultivated in Egyptian soils, especially in Ismailia governorate.

\section{MATERIALS AND METHODS}

\section{Field experiment}

A field experiment was carried out during the summer season $(2019 / 2020)$ at the experimental site of Faculty of Agriculture of Suez Canal University, Ismailia, Egypt, to evaluate the effect of hydrogel on tomato (Solanum lycopersicum) growth, soil available nutrients content and soil chemical properties. Some physical and chemical properties of a sandy soil before planting were shown in Table (1). The experiment was laid out in a randomized complete block design having three replicates using drip irrigation system. The experimental plot was $100 \mathrm{~m}^{2}$ included 18 lines each with $5.5 \mathrm{~m}$ in length and $1 \mathrm{~m}$ in width and the planting distance $30 \mathrm{~cm}$ between the plants. The experimental treatments comprised of control (without any fertilizer), two hydrogel levels $\left(\mathrm{HG}_{1}, 2 \mathrm{~g}\right.$ plant ${ }^{-1}$ and $\mathrm{HG}_{2}, 4 \mathrm{~g}$ plant $\left.^{-1}\right)$, recommended fertilizers for tomato $(\mathrm{F})$ and combination of hydrogel and half amounts of recommended fertilizers $\left(\mathrm{HG}_{1}+0.5 \mathrm{~F}\right.$ and $\left.\mathrm{HG}_{2}+0.5 \mathrm{~F}\right)$.

Hydrogel and other treatments were thoroughly mixed at surface layer $(0-15 \mathrm{~cm})$ of the soil for each plant. The recommended amounts of fertilizers were 39 $\mathrm{kg} \mathrm{P}_{2} \mathrm{O}_{5}$ fed $^{-1}, 20.5 \mathrm{~kg} \mathrm{~N} \mathrm{fed}^{-1}$ and $24 \mathrm{~kg} \mathrm{~K}_{2} \mathrm{O}$ fed $^{-1}$. The fertilizers used in the experiment namely potassium phosphate, diammonium phosphate and potassium sulfate, were applied three times through the experimental period. Some properties of hydrogel are shown at Table (2). 
Soil samples measurements, plant growth parameters and nutrient content

The soil samples were dried by a $2 \mathrm{~mm}$ screen and analyzed using standard procedures for electrical conductivity $\left(\mathrm{EC}\right.$ in $\left.\mathrm{dSm}^{-1}\right), \mathrm{pH} \quad(1: 2.5)$, available nitrogen, phosphorus, and potassium were determined according to (Burt, 2004). After physiological maturity, ten plants were taken from each treatment at random select for measuring fruit yield per plant $\left(\mathrm{g}\right.$ plant $\left.{ }^{-1}\right)$, branch number, shoot length $(\mathrm{cm})$, root length $(\mathrm{cm})$, shoot and root dry weight $(\mathrm{g})$. The samples of tomato plants dried at $70^{\circ} \mathrm{C}$ after that the samples were grinding and stored for analysis. Samples were digested by $\mathrm{H}_{2} \mathrm{SO}_{4}$ and $\mathrm{H}_{2} \mathrm{O}_{2}$ then were analyzed for $\mathrm{N}, \mathrm{P}$ and $\mathrm{K}$ as described by (Page et al., 1982).

Table (1): Some properties of the soil at the beginning of the experiment

\begin{tabular}{|c|c|}
\hline Properties & \\
\hline Particle size distribution \% & \\
\hline Sand & 92.5 \\
\hline Silt & 5.50 \\
\hline Clay & 2.00 \\
\hline Texture class & Sand \\
\hline $\mathrm{pH}(1: 2.5)$ & 7.50 \\
\hline $\mathrm{EC}\left(\mathrm{dSm}^{-1}\right)$ & 1.40 \\
\hline Soluble cations $\left(\mathrm{meql}^{-1}\right)^{*}$ & \\
\hline $\mathrm{Ca}^{2+}$ & 2.20 \\
\hline $\mathrm{Mg}^{2+}$ & 4.80 \\
\hline $\mathrm{Na}^{+}$ & 3.80 \\
\hline $\mathrm{K}^{+}$ & 3.20 \\
\hline Soluble anions $\left(\mathrm{meql}^{-1}\right)^{*}$ & \\
\hline$\overline{\mathrm{CO}_{3}{ }^{2-}}$ & 0.00 \\
\hline $\mathrm{HCO}_{3}^{-}$ & 3.50 \\
\hline $\mathrm{Cl}^{-}$ & 7.00 \\
\hline $\mathrm{SO}_{4}^{2-}$ & 3.50 \\
\hline Available N $\left(\mathrm{mgkg}^{-1}\right)$ & 3.00 \\
\hline Available $\mathrm{P} \quad\left(\mathrm{mgkg}^{-1}\right)$ & 20.0 \\
\hline Available K $\left(\mathrm{mgkg}^{-1}\right)$ & 300 \\
\hline $\begin{array}{l}\text { Cation Exchangeable Capacity } \\
\text { (CEC) c mol kg-1 }\end{array}$ & 9.00 \\
\hline
\end{tabular}

*In soil paste extraction

Table (2): Some properties of applied hydrogel (barbary plante)

\begin{tabular}{lc}
\hline Properties & \\
\hline Appearance & $\begin{array}{c}\text { White to Slightly green } \\
\text { grains }\end{array}$ \\
Grain size (mm) & $1-2.5$ \\
Bulk density $\left(\mathbf{g ~ c m}^{-3}\right)$ & 0.7 \\
Solubility & Insoluble in water \\
pH in distilled water & 6.5 \\
(1:100) & \\
Absorption capacity & 400 \\
(g/g gel) & 1 \\
Absorption time (hours) & 605 \\
CEC c mol kg & \\
\hline
\end{tabular}

\section{RESULTS AND DISCUSSION}

Effect of hydrogel fertilizer on tomato growth parameters and nutrient content

Results presented at Figures $(1-4)$ reveal some growth parameters of the tomato (Solanum lycopersicum L.) plants due to using hydrogel. The effect of hydrogel on the number of branches plant ${ }^{-1}$ of the tomato plant is shown in Figure (1). It was found that the highest number of branches for plants was in the case of treatment $4 \mathrm{~g}$ hydrogel + half the recommended amount of fertilizer $\left(\mathrm{HG}_{2}+0.5 \mathrm{~F}\right)$, followed by an addition of $4 \mathrm{~g}$ hydrogel per plant $\left(\mathrm{HG}_{2}\right)$. In general, the number of plant branches in the case of adding hydrogel or with half the recommended amount of fertilizer, is higher than when adding fertilizers. This finding agrees with (Sultana et al., 2016) who found that the application of super water absorbent hydrogel $(0.5 \%$ SWA) increased branch number of tomatoes from 14 in soil untreated with SWA to 20 in soil treated with SWA.

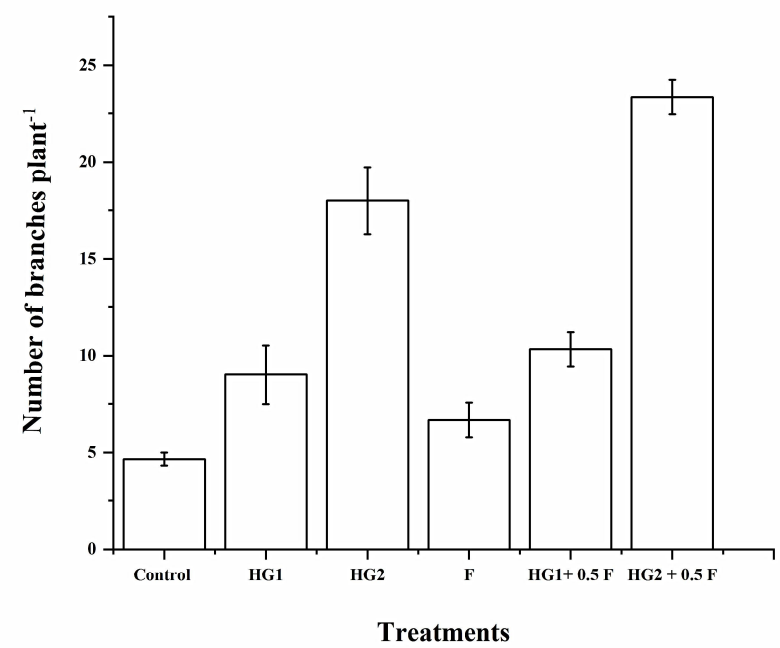

Fig (1): Effect of hydrogel application on branch number plant ${ }^{-1}$ of tomato plants

As for the shoot growth of tomato plants, it is shown in Figures ( $2 \mathrm{a}$ and $\mathrm{b}$ ) in terms of the shoot length $(\mathrm{cm})$ and dry weight $(\mathrm{g})$. The results show that the shoot length in all treatments with added hydrogel fertilizer are greater than in the case of control or when chemical fertilizers only were applied. These results are compatible with (Yazdani et al., 2007) who observed that soybean height increased with application of super water absorbent hydrogel. Also, the highest dry weight of the shoots was in the case of treatments $2,4 \mathrm{~g}$ with adding half of the recommended amount of fertilizer.

Effect of hydrogel fertilizer application on root growth was shown in Figures ( $3 \mathrm{a}$ and $\mathrm{b}$ ). The results show that the highest root length was recorded in the treatment $4 \mathrm{~g}$ with half the recommended amount of fertilizer $\left(\mathrm{HG}_{2}+0.5 \mathrm{~F}\right)$, followed by the addition of only $4 \mathrm{~g}\left(\mathrm{HG}_{2}\right)$ of hydrogel treatment, followed by the other treatments. Moreover, the highest value of root dry weight was obtained with the treatment $2 \mathrm{~g}$ with half the recommended amount of fertilizer $\left(\mathrm{HG}_{1}+0.5 \mathrm{~F}\right)$. In general, the addition of hydrogel fertilizer leads to an 
increase in the dry weight of the roots. These results may show the ability of the hydrogel to retain water and nutrients in the root zone of the plant, which works to
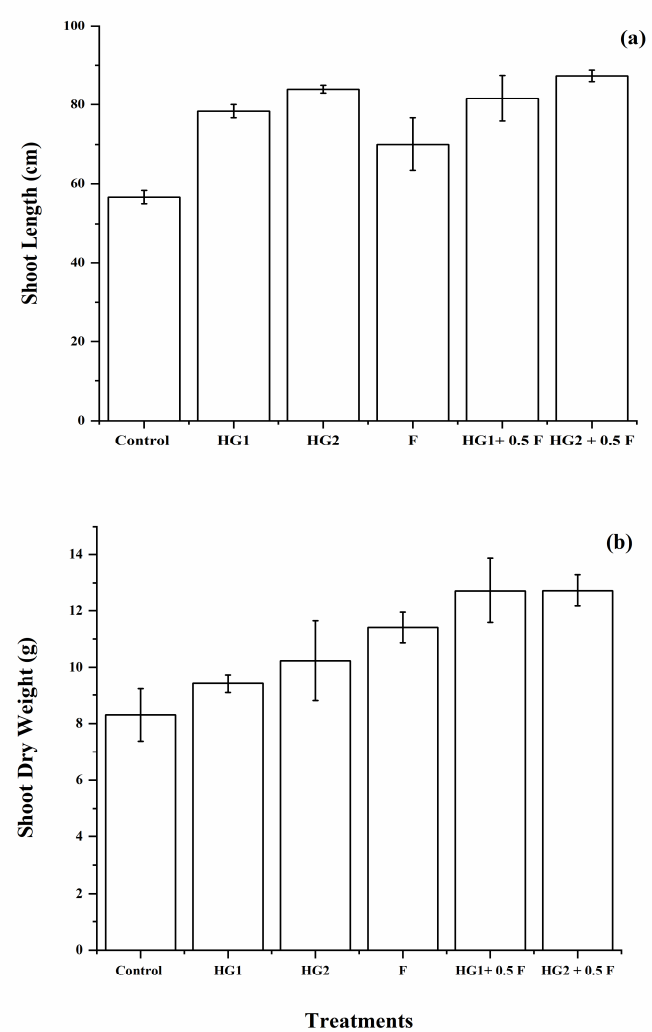

Fig (2): Effect of hydrogel application on tomato shoot growth where, a) shoot length $(\mathrm{cm})$ and $\mathrm{b}$ ) shoot dry weight $(\mathrm{g})$

Regarding the number and weight of tomato fruits in the experiment, the results indicated that the highest number and weight of fruits were recorded in the treatment of $4 \mathrm{gm}$ hydrogel per plant $\left(\mathrm{HG}_{2}\right)$, followed by the treatment in which $4 \mathrm{~g}$ was added with half of the recommended amount of fertilizer $\left(\mathrm{HG}_{2}+0.5 \mathrm{~F}\right)$. The lowest number and weight of fruits were found in the two treatments, i.e., control (C) and adding only chemical fertilizers $(\mathrm{F})$, respectively, as shown in the release them slowly to be absorbed by the plant (Hüttermann et al. (1999) and Tomaszewska and Jarosiewicz (2002).
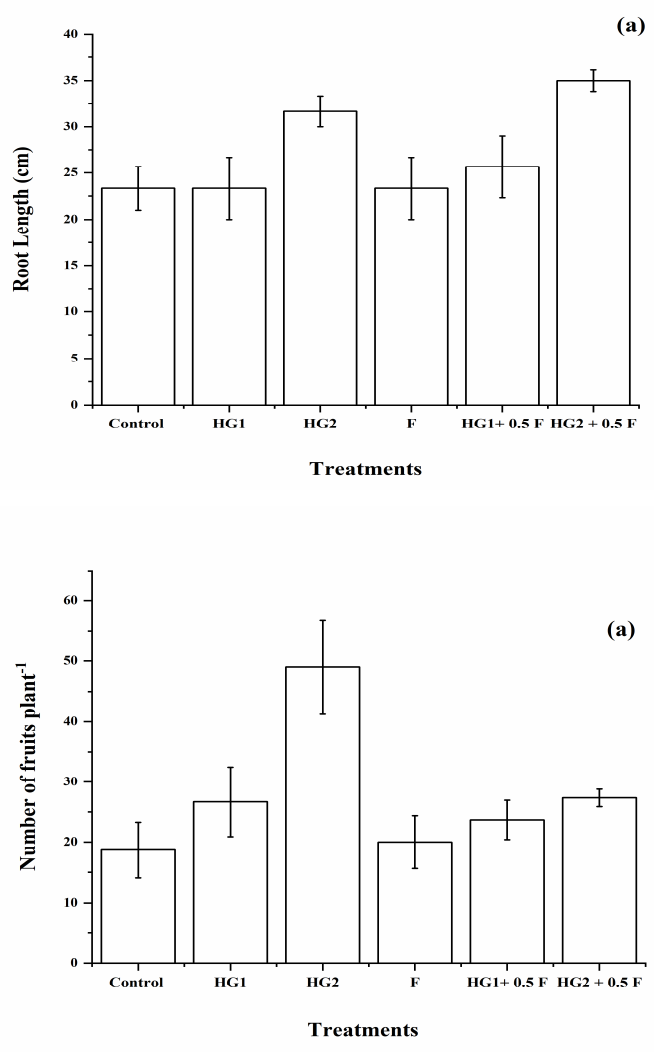

Fig (3): Effect of hydrogel application on tomato root growth where, a) root length $(\mathrm{cm})$ and $\mathrm{b}$ ) root dry weight $(\mathrm{g})$

Figure (4 a \& b). This may be attributed to the availability of hydrogel fertilizer for fast nutrient delivery to the plant and water in the root zone, resulting in an increase in nutrient absorption within the plant, which leads to an increase in production. These results are compatible with Ahmed and Fahmy (2019); Sultana et al. (2016) and Yazdani et al. (2007) who reported that, the application of super water absorbent hydrogel increased plant production.

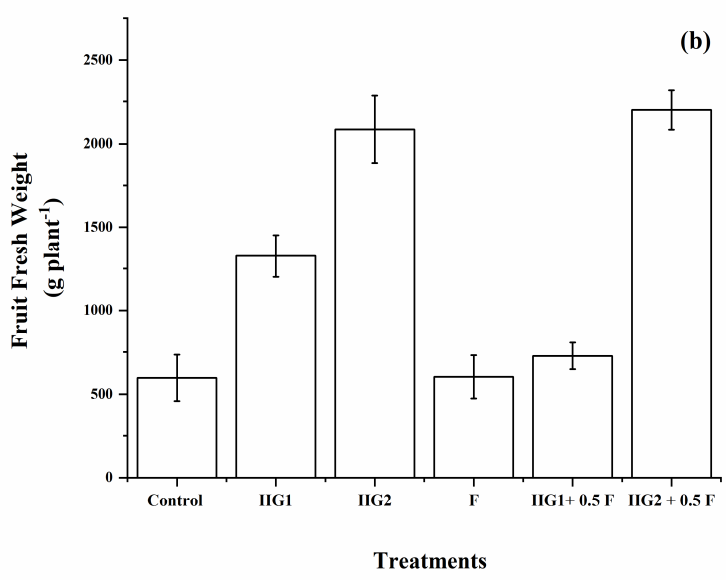

Fig (4): Effect of hydrogel application on tomato fruits where, a) fruit number plant ${ }^{-1}$ and b) fruit fresh weight $\left(\mathrm{g} \mathrm{plant}^{-1}\right)$ 
Nutrient content in tomato plants (shoot, root and fruits) were shown in Table (3). Tomato treated with $4 \mathrm{~g}$ hydrogel in soil showed the highest content of N, P and $\mathrm{K}$ in shoot in addition to $\mathrm{N}$ and $\mathrm{K}$ in root. Furthermore, the highest content of $\mathrm{N}, \mathrm{P}$ and $\mathrm{K}$ were recorded in fruits of tomato treated with $4 \mathrm{~g}$ hydrogel with half amount of recommended fertilizer $\left(\mathrm{HG}_{2}+0.5 \mathrm{~F}\right)$ compared to control. It has been noticed that there is a significant increase in the nutrient content in plants by using hydrogel. This result in agreement with those of El-Hady et al. (2012) who found that adding hydrogel as a conditioner to organic compost in sandy soil improved water and nutrient use efficiency for tomato plants. Hydrogel application reduces the amount of fertilization needed by preventing nutrients from leaching and increasing water consumption. Hydrogels that contain fertilizers and have a regulated water release, allowing the fertilizer dose to be adjusted over time. Thus, the nutrients are available to the plant for a longest period of time (Abobatta, 2018; Ni et al., 2009; Rahman et al., 2001). Briefly, hydrogels indirectly affect nutrients uptake by conservation soil moisture and nutrients mobility (El-Hady et al., 2003).

\section{Effect of hydrogel fertilizer on some soil chemical properties}

Some soil chemical properties were shown at Table (4). The results showed that there was no difference in soil salinity values till the end of the experiment. Among soil chemical properties, soil $\mathrm{pH}$ is the most important property of soil. Hence, soil $\mathrm{pH}$ influences soil chemical transformations and nutrient availability to plants. In this study, all treatments with hydrogel provided a slight decrease in soil $\mathrm{pH}$ values. The decreases in soil $\mathrm{pH}$ were ranged between 0.08 and 0.18 unites by adding $2 \mathrm{~g}\left(\mathrm{HG}_{1}\right)$ and $4 \mathrm{~g}\left(\mathrm{HG}_{2}\right)$ of hydrogel in the rootzone of plants. While using hydrogel with $50 \%$ fertilizers, the $\mathrm{pH}$ decreased by 0.05 and 0.14 unites, respectively. The longer the hydrogel in the soil, the higher the acidity. These results were compatible with El-Saied et al. (2016)) and Rajakumar and Sankar (2016) who found that dissociation of $\mathrm{H}^{+}$ from hydrogel, other cation-cation like functional group to the surface results in negative charge, which neutralizes cation exchange sites and causes an increase in soil acidity.

One of the most significant limitations of soil fertility in sandy soil is its low CEC, and thus its low specific surface area. Data referred that, adding hydrogel to soil increases CEC (Table 4). The addition of hydrogel at the highest rate $(4 \mathrm{~g})$ with half of the recommended amounts of fertilizers $\left(\mathrm{HG}_{2}+0.5 \mathrm{~F}\right)$ led to an increase in the value of the soil CEC (11.5 \pm 0.12$)$ compared to the other treatments. The results showed that adding only $2 \mathrm{~g}$ of hydrogel has no effect on CEC. In general, the addition of hydrogel only or with half recommended fertilizers led to an increase in CEC in the root zone as compared to the control treatment. Also, found that the CEC of hydrogel-treated soil was 1.8 and 2.1 times greater than the control treatment, which included 2 and $4 \mathrm{~g}$ hydrogel per plant, respectively. These results may be due to the high CEC of hydrogel (605 $\left.\mathrm{c} \mathrm{mol} \mathrm{kg}^{-1}\right)$ (El-Saied et al., 2016).

Regarding the soil nutrient availability, it is well known that the sandy soils have a low content of nutrients. Data in Table (4) that the available N, P and K were $3.47 \pm 0.15,21 \pm 1.5$ and $283 \pm 4$, respectively in soil without hydrogel (control). There were increases in the availability of $\mathrm{N}, \mathrm{P}$ and $\mathrm{K}$ by applying 2 and $4 \mathrm{~g}$ of hydrogel per plant. The highest value of available N, P and $K$ were $15.8 \pm 0.9,78 \pm 1.5$ and $343 \pm 23 \mathrm{mgkg}^{-1}$, respectively, at the treatment $4 \mathrm{~g}$ hydrogel with the half amounts of recommended fertilizers. These results were consistent with those of Abobatta (2018), Rajakumar and Sankar (2016) and El-Hady et al. (2009). This result may be due to the high absorption of water by hydrogels from the soil, and the nutrients that dissolve in the soil solution or from fertilizer solutions which can be adsorbed on its surface. Also, the absorbed nutrients can be released slowly between nutrients in soil solution and hydrogels (El-Saied et al., 2016; El-Hady et al., 2009).

\section{CONCLUSION}

Sandy soil is known as a low fertility soil and plants suffer to get their nutrient requirements. By adding hydrogel to soil, plant growth and some soil chemical properties were improved as following;

1. An increase in tomato growth parameters such as, branches number, shoot and root dry weight, shoot and root length, fruit number and fruit weight per plant.

2. An increase in $\mathrm{N}, \mathrm{P}$ and $\mathrm{K}$ uptake by plants.

3. A decreased in soil $\mathrm{pH}$.

4. An increase in cation exchangeable capacity of the soil.

5. An increase in nutrient availability.

Also, hydrogel reduce the cost and efforts of fertilizers addition and fertilization process as it was applied once from the beginning of the experiment $\left(\mathrm{HG}_{1}, \mathrm{HG}_{2}, \mathrm{HG}_{1}+0.5 \mathrm{~F}\right.$ and $\left.\mathrm{HG}_{2}+0.5 \mathrm{~F}\right)$ compared to fertilizers $(F)$ which were added three times through the growth season.

\section{REFERENCES}

Abobatta, W. (2018). Impact of hydrogel polymer in agricultural sector. Adv. Agric. Environ. Sci. Open Access, 1: 163-172.

Ahmed, S. and A. Fahmy (2019). Applications of Natural Polysaccharide Polymers to Overcome Water Scarcity on the Yield and Quality of Tomato Fruits. J. Soil Sci. Agric. Eng., 10: 199-208.

Burt, R. (2004). Soil Survey Laboratory Methods Manual. Soil Survey Investigations Report no. 42, version 4.0. report no. 42, version 4.0. Nat. Resour. Conserv. Serv. US Dep. Agric. Washington, DC

Dehkordi, D. K. and S. Seyyedboveir (2013). Evaluation of super AB A 200 Superabsorbent on water use efficiency and yield response factor of SCKaroun 701 corn under deficit irrigation. Adv. Environ. Biol., 4615-4623. 
Table (3): Effect of hydrogel fertilizer on nutrients content ( $\mathrm{gkg}^{-1}$ dry weight) in tomato

\begin{tabular}{|c|c|c|c|c|c|c|c|c|c|}
\hline \multirow{3}{*}{ Treatments } & \multicolumn{3}{|c|}{ Shoot } & \multicolumn{3}{|c|}{ Root } & \multicolumn{3}{|c|}{ Fruits } \\
\hline & $\mathbf{N}$ & $\mathbf{P}$ & $\mathbf{K}$ & $\mathbf{N}$ & $\mathbf{P}$ & $\mathbf{K}$ & $\mathbf{N}$ & $\mathbf{P}$ & $\mathbf{K}$ \\
\hline & \multicolumn{9}{|c|}{ gkg $^{-1}$ dry weight } \\
\hline Control $^{*}$ & $14.84^{\mathrm{c}} \pm 0.71$ & $0.92^{\mathrm{b}} \pm 0.05$ & $9.57^{\mathrm{d}} \pm 0.26$ & $10.9^{\mathrm{a}} \pm 0.1$ & $1.03^{\mathrm{b}} \pm 0.19$ & $9.21^{\mathrm{c}} \pm 0.68$ & $14.78^{\mathrm{c}} \pm 0.61$ & $1.45^{\mathrm{a}} \pm 0.30$ & $15.94^{\mathrm{c}} \pm 0.02$ \\
\hline $\mathbf{H G}_{1}$ & $18.34^{\mathrm{b}} \pm 0.98$ & $1.42^{\mathrm{a}} \pm 0.06$ & $13.78^{\mathrm{b}} \pm 0.77$ & $11.2^{\mathrm{a}} \pm 0.25$ & $1.44^{\mathrm{a}} \pm 0.03$ & $10.71^{\mathrm{bc}} \pm 1.4$ & $20.30^{\mathrm{bc}} \pm 1.82$ & $1.79^{\mathrm{a}} \pm 0.03$ & $17.81^{\mathrm{ab}} \pm 0.16$ \\
\hline $\mathbf{H G}_{2}$ & $22.07^{\mathrm{a}} \pm 0.71$ & $1.5^{\mathrm{a}} \pm 0.07$ & $16.85^{\mathrm{a}} \pm 0.99$ & $12.7^{\mathrm{a}} \pm 0.80$ & $1.31^{\mathrm{ab}} \pm 0.14$ & $13.18^{\mathrm{ab}} \pm 0.18$ & $25.20^{\mathrm{b}} \pm 1.85$ & $1.83^{\mathrm{a}} \pm 0.21$ & $17.69^{\mathrm{ab}} \pm 0.28$ \\
\hline $\mathbf{F}$ & $15.07^{\mathrm{c}} \pm 1.12$ & $1.38^{\mathrm{a}} \pm 0.24$ & $14.68^{\mathrm{ab}} \pm 1.67$ & $13.6^{\mathrm{a}} \pm 0.9$ & $1.51^{\mathrm{a}} \pm 0.02$ & $15.11^{\mathrm{a}} \pm 1.8$ & $19.41^{b c} \pm 0.85$ & $1.69^{\mathrm{a}} \pm 0.40$ & $17.09^{\mathrm{b}} \pm 0.37$ \\
\hline $\mathrm{HG}_{1}+0.5 \mathrm{~F}$ & $15.17^{\mathrm{c}} \pm 0.12$ & $1.41^{\mathrm{a}} \pm 0.01$ & $10.89^{\mathrm{cd}} \pm 0.12$ & $13.4^{\mathrm{a}} \pm 0.2$ & $1.45^{\mathrm{a}} \pm 0.05$ & $12.59^{\mathrm{abc}} \pm 0.21$ & $25.53^{\mathrm{b}} \pm 1.61$ & $1.83^{\mathrm{a}} \pm 0.14$ & $18.04^{\mathrm{a}} \pm 0.27$ \\
\hline $\mathrm{HG}_{2}+0.5 \mathrm{~F}$ & $18.03^{\mathrm{b}} \pm 0.15$ & $1.48^{\mathrm{a}} \pm 0.09$ & $13.00^{\mathrm{bc}} \pm 0.29$ & $12.13^{\mathrm{a}} \pm 0.20$ & $1.43^{\mathrm{a}} \pm 0.07$ & $15.63^{\mathrm{a}} \pm 0.35$ & $36.53^{\mathrm{a}} \pm 0.33$ & $1.89^{\mathrm{a}} \pm 0.06$ & $19.53^{\mathrm{a}} \pm 0.38$ \\
\hline
\end{tabular}

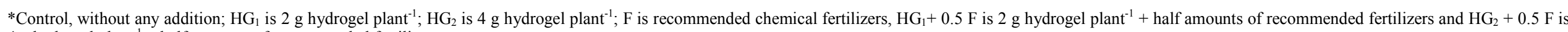
$4 \mathrm{~g}$ hydrogel plant ${ }^{-1}+$ half amounts of recommended fertilizers 
El-Hady, O. A., A. A. A. El-Kader and A. M. Shafi (2009). Physico-bio-chemical properties of sandy soil conditioned with acrylamide hydrogels after cucumber plantation. Aust. J. Basic Appl. Sci., 3: 3145-3151.

El-Hady, O. A., N. A. Rizk and E. S. El-Saify (2003). The potentiality for improving plant-soil-water relations in sandy soils using some synthesized Am Na (or K) ATEA hydrogels. Egypt. J. Soil Sci.

El-Hady, O. A., S. M. Shaaban and S. A. Wanas (2012). Effect of hydrogels and organic composts on soil hydrophysical properties and on production of tomato. Acta Hortic., 933: 115122.

El-Saied, H., O. A. El-Hady, A. H. Basta, C. Y. ElDewiny and S. A. Abo-Sedera (2016). Biochemical properties of sandy calcareous soil treated with rice straw-based hydrogels. J. Saudi Soc. Agric. Sci., 15: 188-194.

Hoang, T. T. H., T. C. Phan, M. T. Hoang, W. Chen and R. W. Bell (2010). Sandy soils in South Central Coastal Vietnam: Their origin, constraints and management.

Ni, B., M. Liu and S. Lü (2009). Multifunctional slowrelease urea fertilizer from ethylcellulose and superabsorbent coated formulations. Chem. Eng. J., 155: 892-898.

Page, A. L., R. H. Miller and D. R. Keeney (1982). Methods of soil analysis. Part 2. Chemical and
Microbiological Properties. $2^{\text {nd }}$ Am. Soc. Agron. Inc. Publisher Madison, Wisconsin, USA.

Rahman, M. S., A. M. Sarker, M. S. Islam and N. K. Paul (2001). Effect of Soil Moisture on Grain Yield of Wheat (Triticum aestivum L.) Cultivars. Environ. Ecol., 19: 304-308.

Rajakumar, R. and J. Sankar (2016). Hydrogel: Novel soil conditioner and safer delivery vehicle for fertilizers and agrochemicals-A review. Int. J. Appl. Pure Sci. Agric, 2(9): 163-172.

Sultana, S., M. A. Shariff, M. A. Hossain, A. Khatun and R. Huque (2016). Effect of Super water absorbent (SWA) hydrogel on productivity and quality of Tomato. Arch. Appl. Sci. Res., 8: 59.

Tomaszewska, M. and A. Jarosiewicz (2002). Use of polysulfone in controlled-release NPK fertilizer formulations. J. Agric. Food Chem., 50: 4634-4639.

Yazdani, F., I. Allahdadi and G. A. Akbari (2007). Impact of superabsorbent polymer on yield and growth analysis of soybean (Glycine max L.) under drought stress condition. Pak. J. Biol. Sci., 10: 4190-4196.

Yousefzadeh, P., M. Sohrabpour and M. S. Khadjavi (1994). Radiochemical preparation of polyacrylamide hydrogels and their use in agriculture. (No. IAEA-TECDOC--768).

\section{فاعلية إضافة الهيدروجيل على نمو نبات الطماطم وبعض الخواص الكيميائية للتربة الرملية تحت نظام الري بالتنقيط

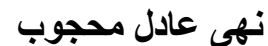$$
\text { قسم الأراضي و المياه ـ كلية الزر اعة ـ جامعة قناة السويس ـ الاسماعيلية ـ مصر }
$$

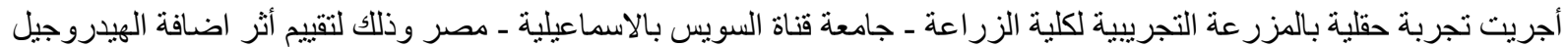

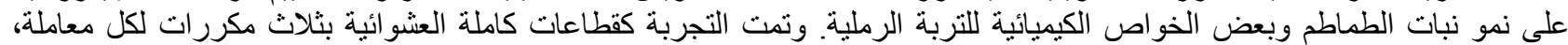

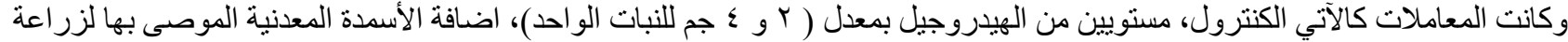

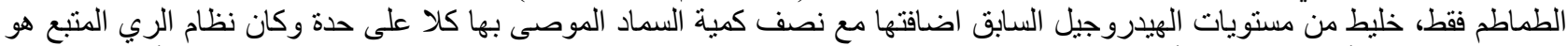

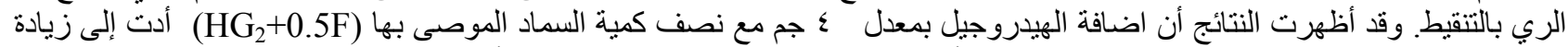

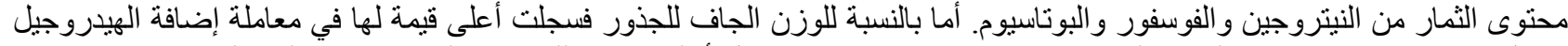

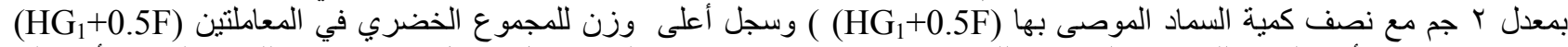

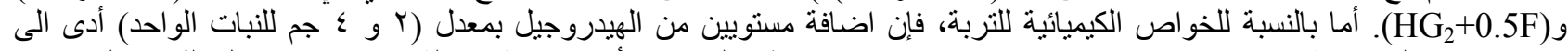

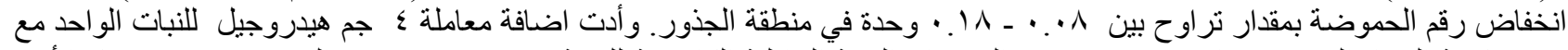

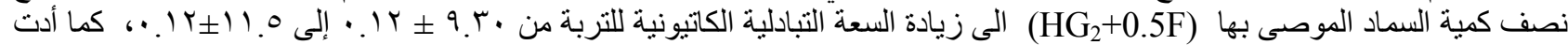

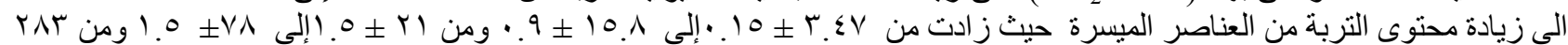

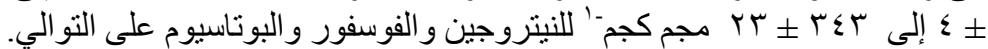

